\title{
Highly Selective Anion Recognition, Extraction and Deep Removal Us- ing a Superphane
}

\author{
Wei Zhou, ${ }^{\dagger}$ Aimin Li, ${ }^{\dagger}$ and Qing $\mathrm{He}^{*, \dagger}$ \\ †State Key Laboratory of Chemo/Biosensing and Chemometrics, Advanced Catalytic Engineer Research Center of the \\ Ministry of Education, College of Chemistry and Chemical Engineering, Hunan University, Changsha 410082, P.R. \\ China \\ KEYWORDS: Superphane; Cyclophane; Perrhenate; Solid-liquid extraction ; Liquid-liquid extraction ; Organic cages
}

\begin{abstract}
Highly selective anion recognition and extraction are critical and challenging to deep removal of pollutants from the environment and effective recovery of valuable chemicals from low-content (at sub-ppm or ppb level) sources. Herein, we detail the gram-scale synthesis of a superphane 2 , a new supramolecular host that was found capable of encapsulating $\mathrm{ReO}_{4}^{-}$with high selectivity, as suggested by the single-crystal structures, NMR spectroscopy and theoretical calculations. Under solid-liquid extraction condidtions, 2 proved able to extract perrhenate from the solid mixture containing trace $\mathrm{ReO}_{4}$ (as low as $200 \mathrm{ppb}$ ) with near $100 \%$ selectivity over other 7 competing anions. Under liquid-liquid extraction conditions, using 2 as the supramolecular extractant, over $99.99 \%$ of $\mathrm{ReO}_{4^{-}}$could be separated from the complex simulated aqueous waste streams containing ppm-level perrhenate and large excess of competing ions. Notably, after extraction, $\mathbf{2}$ could be recycled and reused by simple treatment with $\mathrm{NaHCO}_{3}$. This study opens up the door to development of superphane-based advanced materials for deep elimination of pollutants from the envirenment and purification of chemicals of interest with high efficiency and selectivity.
\end{abstract}

\section{Introduction}

Rhenium is a naturally occurring rare metallic element with the least abundance both in the crust of the earth and in the solar system. ${ }^{1}$ Due to its widespread use in petrochemical industry, aviation space, high-tech products and emerging innovation, the demand for rhenium has become an increasingly urgent issue in recent years. ${ }^{2-6}$ To date, there are no economic processing methods for producing rhenium as the primary commodity, due to the lack of primary rhenium deposits in nature. ${ }^{7-8}$ Instead, rhenium is usually extracted from solid and liquid by-products of molybdenum and copper industries, wherein the rhenium contents are typically found in the range of $200-800 \mathrm{ppm}$ in the former concentrates and $10-50 \mathrm{ppm}$ in the latter concentrates, respectively. ${ }^{9-10}$ Besides, deep removal of hazardous and radioactive $\mathrm{TcO}_{4}^{-}\left(\mathrm{ReO}_{4}^{-}\right.$is used as its structural surrogate) is of particular importance in nuclear waste management to avoid potential enviorenment pollutants. ${ }^{11-}$ ${ }^{12}$ These provide an incentive to develop new strategies that might allow low-content (at the ppm level) rhenium to be effectively and selectively isolated from rhenium-bearing resources, such as the leaching liquors of natural rhenium mineral and rhenium-containing spent wastes, in which $\mathrm{ReO}_{4}{ }^{-}$is expected to be the dominant rhenium form. ${ }^{3,13}$ In this regard, both solid-liquid extraction (SLE) and liquidliquid extraction (LLE) strategies are appealing. However, the quest for extractants or adsorbents with high efficacy and selectivity towards perrhenate remains a challenging and perpetual task. Herein, we detail the synthesis and host-guest binding property of a superphane (2) that allow $\mathrm{ReO}_{4}{ }^{-}$to be encapsulated and extracted efficiently and selectively under both SLE and LLE conditions. To the best of our knowledge, system 2 represents the first superphanebased receptor for extraction ( $>99.99 \%$ efficiency) of $\mathrm{ReO}_{4}{ }^{-}$ with exceptionally high selectivity from low-content rhenium bearing source (as low as $200 \mathrm{ppb}$ ) to organic chloroform phase.

During the course of rhenium production, anion exchange and solvent extraction prove critical to commercial practice for the enrichment of rhenium.3, 14 The past decades have witnessed significant advances in designing sorbent materials for removing $\mathrm{ReO}_{4}{ }^{-} / \mathrm{TcO}_{4}{ }^{-}$from aqueous solution by adsorption via anion exchange. ${ }^{15-16}$ Likewise, solvent extraction offers an useful alternate to the efficient isolation of targeted $\mathrm{ReO}_{4}{ }^{-} / \mathrm{TcO}_{4}{ }^{-} \cdot{ }^{3,}{ }^{14}$ Compared with the conventional solvent extraction systems simply based on solubility or ion exchange, supramolecular extraction offers more possibilities to better control the affinity, efficacy and selectivity of the extractants required especially for their uses in the realworld scenarios. ${ }^{17}$ Although many recent advances and successes have been achieved in molecular recognition chemistry, the chemistry of $\mathrm{ReO}_{4}^{-} / \mathrm{TcO}_{4}^{-}$receptors, especially for effective $\mathrm{ReO}_{4}{ }^{-}$extraction, is not well developed. ${ }^{18-22}$ For example, in 2012, Amendola et al. reported the first molecular receptor, an azacryptand in its protonated form, to effectively trap ${ }^{99} \mathrm{TcO}_{4}{ }^{-}$in aqueous solution. ${ }^{20}$ Recently, Nitschke and coworkers established an self-assembling $\mathrm{Fe}^{\mathrm{II}_{4}} \mathrm{~L}_{4}$ cage, that is able to extract an equimolar amount of $\mathrm{ReO}_{4}{ }^{-}$with decent selectivity. ${ }^{21}$ Impressive as these recent results were, 
ongoing search for new systems aiming at effective and selective extraction of $\mathrm{ReO}_{4}^{-}$is needed to meet the requirements for the real scenarios. (a) Classical superphane

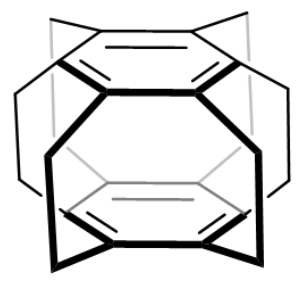

1 (b) New superphane (this work)

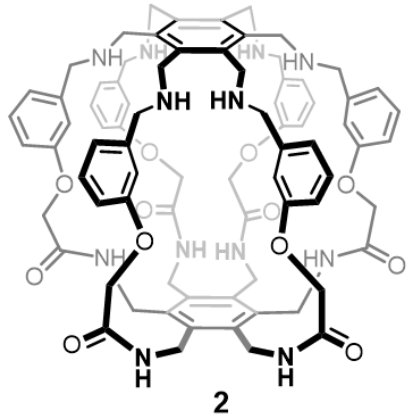

Figure 1. Chemical structures of (a) a classical superphane (1) without binding cavity reported in the literature and (b) a new superphane (2) with a well-defined binding aperture reported in this work.

Direct extraction of $\mathrm{ReO}_{4}{ }^{-}$from solid mixtures or aqueous solutions into organic phases, e.g. chloroform phase, under conditions with low-content $\mathrm{ReO}_{4}{ }^{-}$and abundant competing species such as $\mathrm{SO}_{4}{ }^{2-}, \mathrm{ClO}_{4}^{-}, \mathrm{H}_{2} \mathrm{PO}_{4}^{-}$, and $\mathrm{MoO}_{4}^{-}$, remains challenging. To achieve this goal, new receptors for $\mathrm{ReO}_{4}{ }^{-}$should be well-tailored with exceptional effectiveness and selectivity, which, we envisioned, might be enhanced if an anion receptor features (1) multiple anionic binding sites; (2) uniform distribution of the binding sites around the 3D cavity; (3) near-enclosed binding pocket to prevent the bound anion from solvation. Such considerations led us to postulate that superphanes, compounds in which the two benzene rings clamped parallel on top of each other by six bridges, ${ }^{23-26}$ could be most promising candidates. However, conventional superphanes, e.g. 1, have no internal voids for binding any guest species (Figure 1a). Recently, our group reported the synthesis and host-guest chemistry of the first-ever superphane as the supramolecular receptor based on dynamic imine chemistry. ${ }^{27-28}$ Coincidently, Badjić group simultaneously and independently reported a so-called imine-bearing hexapodal capsule for the recognition of anions, e.g. $\mathrm{Cl}^{-}, \mathrm{H}_{2} \mathrm{PO}_{4}{ }^{-}$and $\mathrm{SO}_{4}{ }^{2-}$, using a similar strategy and template effect. ${ }^{29}$ In this contribution, we describe the gram-scale and chromatography-free synthesis of a robust superphane $\mathbf{2}$ (Figure $1 \mathrm{~b}$ ), as well as its highly selective recognition, extraction and deep removal of $\mathrm{ReO}_{4-}^{-}$under both SLE and LLE conditions.

\section{Results and Discussion}

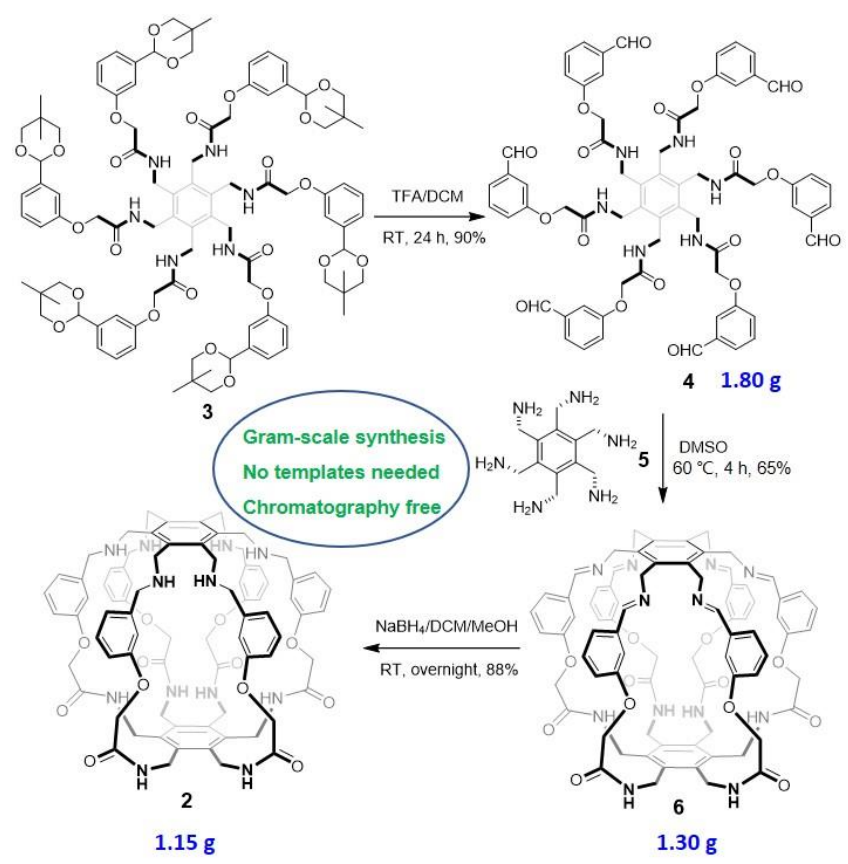

Scheme 1. The synthetic route to superphane 2 via reductive amination.

The synthesis of compound $\mathbf{2}$ is shown in Scheme 1. Specifically, intermediate $\mathbf{3}$ was obtained readily via a simple symmetrical coupling of hexakis(aminomethyl)benzene $\mathbf{5}$ with functionalized 3-hydroxybenzaldehyde (S3) in the presence of 0-benzotriazol-l-yl-tetramethyluroniumhexafluorophosphate (HBTU) and N,N-diisopropylethylamine (DIPEA) in DMF at $50{ }^{\circ} \mathrm{C}$ for $24 \mathrm{~h}$ (Schemes S1-S3). After deprotection of the acetals of $\mathbf{3}$ promoted by TFA in DCM for $24 \mathrm{~h}$ at room temperature, the key hexaaldehyde precursor 4 was afforded in $90 \%$ yield via simple filtration. Subsequently, a condensation of hexaaldehyde 4 and hexakis(aminomethyl)benzene 5 in DMSO at $60^{\circ} \mathrm{C}$ for $4 \mathrm{~h}$ gave the expected imine-based superphane 6 in a ratio of 1:1 in a yield of $65 \%$. Notably, in our current case, anionic templates were not necessary for the formation of desired superphane 6, as opposed to the reported synthesis of an imine-based hexapodal capsule, wherein suitable anions, e.g. $\mathrm{Cl}^{-}, \mathrm{HCO}^{-}, \mathrm{CO}_{3}{ }^{2-}, \mathrm{HPO}_{4}{ }^{2-}$ and $\mathrm{SO}_{4}{ }^{2-}$, were found to be the conditio sine qua non. ${ }^{29}$ To circumvent the instability of imine bonds in 6 , a reductive amination strategy was successfully used to transform superphane 6 into its amine version, namely superphane 2 , with $\mathrm{NaBH}_{4}$ in a mixture of DCM and methanol overnight at room temperature in $88 \%$ yield. In aggregate, a seven-step synthesis of compound 2 from 3 hydroxybenzaldehyde notwithstanding, it is noteworthy that no chromatography is needed for the purification of any intermediates involved and the final product. More importantly, both imine-based superphane $\mathbf{6}$ and secondary amine based superphane 2 can be successfully prepared on gram scale under mild conditions with decent yields given the complexity of the constructs involved (Scheme 1). Compounds $\mathbf{6}$ and $\mathbf{2}$ were fully characterized by standard spectroscopic means, as well as via single-crystal X-ray diffraction analysis (Supporting Information, Schemes S1-S3 and Figures S1-S3). Interestingly, both compounds $\mathbf{6}$ and $\mathbf{2}$ were found to be fluorescence emissive in DMSO or $\mathrm{CHCl}_{3}$ 
with the emission maxima of 452 (ex. $369 \mathrm{~nm}$ ) and $442 \mathrm{~nm}$ (ex. $368 \mathrm{~nm}$ ), respectively (Figures S4 and S5). In the solid state, 6 (quantum yield $\Phi_{\mathrm{f}}=20.2 \%$ ) and $\mathbf{2}\left(\Phi_{\mathrm{f}}=9.8 \%\right.$ ) also display relatively strong fluorescence with the emission maxima of 462 (ex. $379 \mathrm{~nm}$ ) and $403 \mathrm{~nm}$ (ex. $353 \mathrm{~nm}$ ), respectively (Figure S6 and S7).
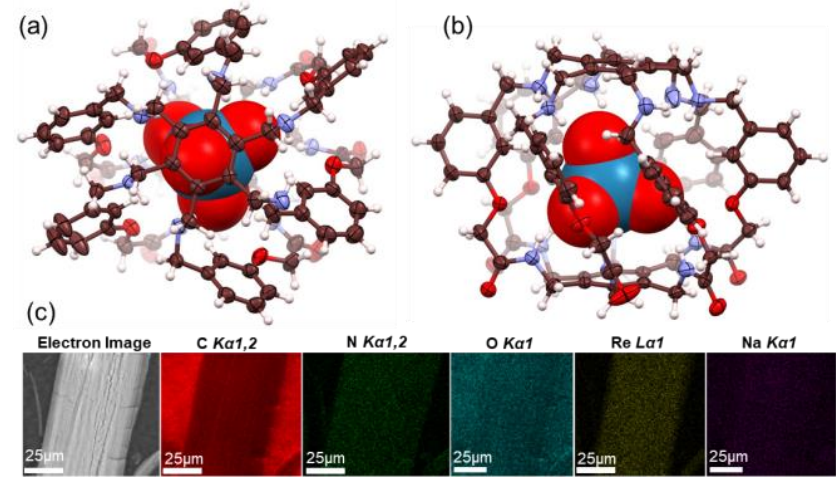

Figure 2. (a) Top view and (b) front view of single crystal structure of $\mathrm{ReO}_{4}-@ 2 \cdot \mathrm{H}^{+}$complex. The host was displayed as ellipsoid model while the perrhenate anion was shown in the space-filling model. All the solvent molecules outside the cavity were removed for clarity. (c) SEM image of a selected single crystal and its SEM/EDS mapping for C, N, O, Re and Na (left to right).

Single crystal structures of 2 revealed that either a DMSO molecule or a $\mathrm{H}_{2} \mathrm{O}-\mathrm{MeOH}$ dimer was found fully entrapped within the inner cavity of $\mathbf{2}$ (Figures S1-S3). This led us to suggest that superphane $\mathbf{2}$ could act as an effective receptor for relatively large guest species, e.g. perrhenate anion $\left(\mathrm{ReO}_{4}{ }^{-}\right)$. Initial evidence for this postulate came from an $\mathrm{X}-$ ray diffraction analysis of single crystals obtained by allowing a chloroform solution of $\mathbf{2}$ to undergo slow evaporation in the presence of excess $\mathrm{NaReO}_{4}$. The resulting structure revealed an encapsulated 1:1 complex in the solid state (Figures 2a and 2b). Due to the removal of disordered solvent molecules outside the cavity using SQUEEZE, ${ }^{30}$ the counter cation, either $\mathrm{Na}^{+}$or $\mathrm{H}^{+}$, was not able to be determined by scattering. However, SEM-EDS (scanning electron microscopy-energy-dispersive spectrometry) analysis of a selected single crystal sample revealed that the crystal consists of marked C, N, O and Re elements but negligible $\mathrm{Na}$ element (Figures 2c, S8 and S9), indicating the occurrence of $\mathrm{ReO}_{4^{-}} @ 2 \cdot \mathrm{H}^{+}$complex. Specifically, superphane $\mathbf{2}$ per se adopts a lantern-shaped conformation and one $\mathrm{ReO}_{4}{ }^{-}$anion was found encapsulated within the deep internal cavity of $\mathbf{2} \cdot \mathrm{H}^{+}$with all six amide $\mathrm{NHs}$ and most of $\mathrm{C}_{\mathrm{sp} 2}-\mathrm{Hs}$ and secondary amine NHs pointing toward the inside cavity, giving rise to exceptionally multiple hydrogen bonds between 2 and perrhenate anion (Figures 2a and 2b). Apparently, up to 18 hydrogen bonds are involved in the stabilization of the tetrahedral perrhenate ion. This $\mathrm{ReO}_{4}{ }^{-} @ \mathbf{2} \cdot \mathrm{H}^{+}$complex in the solid state was also evidenced by a new crystal structure obtained by growing crystals of 2 in the presence of $\mathrm{NH}_{4} \mathrm{ReO}_{4}$, wherein very similar unit cell parameters and single crystal structures were seen (Table S1 and Figure S10). Furthermore, the optimized structure of $\mathrm{ReO}_{4}^{-} @ 2 \cdot \mathrm{H}^{+}$, obtained from DFT calculations, is fully in line with the crystal structures and is characterized by a remarkably favourable binding energy of $-88.5 \mathrm{kcal} \mathrm{mol}^{-1}$ (Figure S11). This highly stable complex was further ascertained by the presumed gas-phase molecular dynamics simulation studies, in which $\mathbf{2} \cdot \mathrm{H}^{+}$and $\mathrm{ReO}_{4}{ }^{-}$can be maintained consistent on the simulation time scale (Figure S12). Notably, as shown in the spacefilling model (Figure S13), the $\mathrm{ReO}_{4}^{-}$anion was nearly imprisoned within the center of the 3D cavity of 2 , a finding that might be of importance to SLE and LLE due, in large part, to the energitically favorable complexation of $\mathrm{ReO}_{4}^{-}$ and the potential protection of the submerged $\mathrm{ReO}_{4}{ }^{-}$anion from solvation.

The ability of receptor 2 to bind perrhenate anions in solution was probed via ${ }^{1} \mathrm{H}$ NMR spectroscopy using $\mathrm{CDCl}_{3}$ as the solvent. Spectroscopic analysis of compound $\mathbf{2}$ revealed only one set of resonances in $\mathrm{CDCl}_{3}$ at room temperature (Figure S14), as would be expected for a relatively flexible system in which different conformations rapidly interconvert. When excess $\mathrm{ReO}_{4}{ }^{-}$as its tetrabutylammonium (TBA) salt was added into a $3.0 \mathrm{mM}$ solution of 2 in $\mathrm{CDCl}_{3}$, the resonance peaks corresponding to receptor 2 were observed to disappear slowly and a new set of peaks ascribable to the perrhenate complex appeared gradually during equilibrium over nine days (Figure S15). Specifically, the $\mathrm{C}_{\mathrm{sp} 2}-\mathrm{Hs}$ at the 2-positions of the phenyl units on the toroidal bridges slightly shifted to downfield while three sets of methylene protons located at $4.86(\boldsymbol{g}), 4.16(\boldsymbol{i})$ and $3.94(\boldsymbol{b})$ ppm underwent shift to $4.58\left(\boldsymbol{g}^{\prime}\right), 4.07\left(\boldsymbol{i}^{\prime}\right)$ and $4.01\left(\boldsymbol{b}^{\prime}\right)$, respectively. These changes are in accord with the conclusion that $\mathrm{ReO}_{4}^{-}$ is being bound effectively by 2 . Due to the kinetically slow equilibrium between superphane 2 and $\mathrm{TBAReO}_{4}$ (Figure $\mathrm{S} 15)$, a mixture solvent system, namely $\mathrm{CDCl}_{3} / \mathrm{CD}_{3} \mathrm{OD}(1: 1$, $\mathrm{v} / \mathrm{v}$ ), was used for ${ }^{1} \mathrm{H}$ NMR spectroscopic titration of 2 with $\mathrm{TBARe}_{4}$. The obtained ${ }^{1} \mathrm{H}$ NMR data corresponding to the phenyl $\mathrm{C}-\mathrm{H}$ proton and methylene signals were fitted to a 1:1 binding model and the resulting binding constant was estimated to be $K_{a}=(5.62 \pm 0.15) \times 10^{3} \mathrm{M}^{-1}$ (Figures S16 and S17).

There usually exist competing anions, e.g. $\mathrm{Cl}^{-}, \mathrm{NO}_{3}{ }^{-}, \mathrm{ClO}_{4}{ }^{-}$, $\mathrm{H}_{2} \mathrm{PO}_{4^{-}}, \mathrm{SO}_{4}{ }^{2-}$, inter alia the latter four, in the $\mathrm{ReO}_{4}-$-bearing resources, such as natural waters and/or nuclear fuel reprocessing streams. ${ }^{31-33}$ To achieve the effective and deep removal of $\mathrm{Re}_{4}^{-}$, its high selectivity over the existing competing anions is critical. We next sought to test whether receptor 2 could bind $\mathrm{ReO}_{4}{ }^{-}$selectively against these competing anions. Initial screening studies were carried out in $\mathrm{CDCl}_{3}$ using ${ }^{1} \mathrm{H}$ NMR spectroscopy (Figure S18). It was found that adding 20 equiv of $\mathrm{Cl}^{-}, \mathrm{NO}_{3}{ }^{-}$, or $\mathrm{ClO}_{4}{ }^{-}$as their TBA salts failed to produce any noticeable changes in the proton signals of $\mathbf{2}$, a finding consistent with a very weak interaction. In sharp contrast, a similar addition of either $\mathrm{H}_{2} \mathrm{PO}_{4}-$ or $\mathrm{SO}_{4}{ }^{2-}$ (as their TBA salts) led to downshifts in the 2-phenyl proton signals (i.e., from 6.76 to $6.81 \mathrm{ppm}$ and $7.00 \mathrm{ppm}$, respectively). Meanwhile, the methylene proton signals were caused to shift from $4.86 \mathrm{ppm}$ to 4.52 and $4.50 \mathrm{ppm}$ respectively. Further detailed ${ }^{1} \mathrm{H}$ NMR spectroscopic titrations of 2 with $\mathrm{TBAH}_{2} \mathrm{PO}_{4}$ or $\mathrm{TBA}_{2} \mathrm{SO}_{4}$ in the same solvent system gave the binding constants of $(2.03 \pm 0.47) \times 10^{3}$ and $(1.07 \pm$ $0.13) \times 10^{3} \mathrm{M}^{-1}$ for $\mathrm{H}_{2} \mathrm{PO}_{4}{ }^{-}$and $\mathrm{SO}_{4}{ }^{2-}$, respectively, by fitting the obtained data to a 1:1 binding model (Figures S19-S22). These findings led us to suggest that receptor 2 binds $\mathrm{ReO}_{4}{ }^{-}$ 
anion with the selectivity being $\mathrm{ReO}_{4}{ }^{-}>\mathrm{H}_{2} \mathrm{PO}_{4}^{-}>\mathrm{SO}_{4}{ }^{2-}>>$ $\mathrm{Cl}^{-}, \mathrm{NO}_{3}{ }^{-}$, or $\mathrm{ClO}_{4}^{-}$.

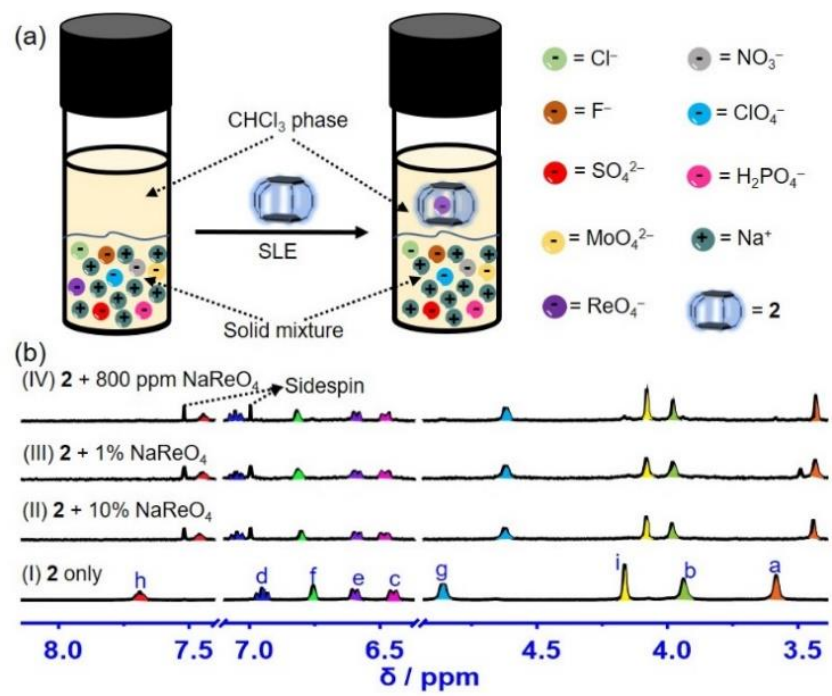

Figure 3. (a) Cartoon illustration of the selective solid-liquid extraction of $\mathrm{ReO}_{4}{ }^{-}$from solid mixtures containing large excess of competing ions. (b) Partial ${ }^{1} \mathrm{H}$ NMR spectra of a $1.0 \mathrm{mM}$ solution of (I) 2 only and $\mathbf{2}$ with solid equal-mass mixtures of $\mathrm{NaCl}$, $\mathrm{NaF}, \mathrm{NaNO}_{3}, \mathrm{NaClO}_{4}, \mathrm{NaH}_{2} \mathrm{PO}_{4}, \mathrm{Na}_{2} \mathrm{SO}_{4}$ and $\mathrm{Na}_{2} \mathrm{MoO}_{4}$ containing (II) $10 \%$, (III) $1 \%$, and (IV) 800 ppm of $\mathrm{NaReO}_{4}$ (mass content). The spectra for (II), (III), and (IV) were recorded after allowing the solid phase and the organic phase to equilibrate for $12 \mathrm{~h}, 24$ $h$, and $72 \mathrm{~h}$, respectively.

The above observations led us to consider that superphane $\mathbf{2}$ might prove effective as a supramolecular extractant for $\mathrm{ReO}_{4}^{-}$under both SLE and LLE conditions even in the presence of excess competing ions, e.g. $\mathrm{Cl}^{-}, \mathrm{NO}_{3}{ }^{-}, \mathrm{ClO}_{4}{ }^{-}$, $\mathrm{H}_{2} \mathrm{PO}_{4^{-}}$, and $\mathrm{SO}_{4}{ }^{2-}$, as would be present in common $\mathrm{ReO}_{4}{ }^{--}$ containing scenarios. Efforts were then made to assess whether superphane 2 was capable of extracting $\mathrm{ReO}_{4}^{-}$under SLE conditions. In a first study, exposing a solution of 2 in $\mathrm{CDCl}_{3}$ to an excess of either powdered $\mathrm{NaReO}_{4}$ or microcrystalline $\mathrm{NH}_{4} \mathrm{ReO}_{4}$ over $6 \mathrm{~h}$ engendered almost identical distinctive changes in the ${ }^{1} \mathrm{H}$ NMR spectrum (Figure S23), suggesting that superphane $\mathbf{2}$ was able to pluck perrhenate anions out of the solids into organic chloroform phase, presumably, in net $\mathrm{HReO}_{4}$ manners, as reflected in the single crystal structure. In contrast, no appreciable changes were observed in the ${ }^{1} \mathrm{H}$ NMR spectra of analogous $\mathrm{CDCl}_{3}$ solutions of cage 2 after exposure to excess solid $\mathrm{NaCl}, \mathrm{NaF}, \mathrm{NaNO}_{3}, \mathrm{NaClO}_{4}, \mathrm{NaH}_{2} \mathrm{PO}_{4}, \mathrm{Na}_{2} \mathrm{SO}_{4}$ and $\mathrm{Na}_{2} \mathrm{MoO}_{4}$, respectively, after equilibration for $6 \mathrm{~h}$ (Figure S24). We thus conclude that receptor $\mathbf{2}$ is able to extract perrhenate ions efficiently and potentially selectively under solid-liquid extraction conditions.

Further support for the fact that, under SLE conditions, superphane $\mathbf{2}$ can act as an effective supramolecular extractant with high selectivity towards $\mathrm{ReO}_{4}^{-}$over its existing competing anions, e.g. $\mathrm{Cl}^{-}, \mathrm{NO}_{3}^{-}, \mathrm{ClO}_{4}^{-}, \mathrm{H}_{2} \mathrm{PO}_{4}^{-}, \mathrm{SO}_{4}{ }^{2-}$, along with $\mathrm{F}^{-}$and $\mathrm{MoO}_{4}^{-}$, came from a series of competition experiments using ${ }^{1} \mathrm{H}$ NMR spectrocopy and inductively coupled mass spectroscopy (ICP-MS) (Figure 3a). Specifically, solutions of $\mathbf{2}$ in $\mathrm{CDCl}_{3}$ were layered over a solid equal-mass mixture of $\mathrm{NaCl}, \mathrm{NaF}, \mathrm{NaNO}_{3}, \mathrm{NaClO}_{4}, \mathrm{NaH}_{2} \mathrm{PO}_{4}$,
$\mathrm{Na}_{2} \mathrm{SO}_{4}$ and $\mathrm{Na}_{2} \mathrm{MoO}_{4}$ containing either $10 \%$ or only $1 \%$ of $\mathrm{NaReO}_{4}$ (by mass) and allowed to stand for $12 \sim 24 \mathrm{~h}$. The resulting spectra gave rise to changes identical to those seen in the presence of solid $\mathrm{NaReO}_{4}$ alone (Figures 3b, S25, S26 and S23). More strikingly, analogous spectral changes were also seen when a similar mixture of salts containing as low as $800 \mathrm{ppm} \mathrm{NaReO}_{4}$ was subject to otherwise identical SLE experiment and allowed equilibration for $72 \mathrm{~h}$ (Figures $3 \mathrm{~b}$ and S27). Towards this end, after a $1.0 \mathrm{mM}$ solution of $\mathbf{2}$ in $\mathrm{CDCl}_{3}$ was placed over a solid mixture as discussed above containing only $200 \mathrm{ppm} \mathrm{NaReO}_{4}$ and subject to equilibration for $48 \mathrm{~h}$. A new set of discernible peaks was seen in the ${ }^{1} \mathrm{H}$ NMR spectrum that was readily assigned to $\mathrm{ReO}_{4}-@ \mathbf{2} \cdot \mathrm{H}^{+}$, along with signals corresponding to free $\mathbf{2}$ (Figure S28). Such observations are taken as an indication that receptor $\mathbf{2}$ works as a super selective extractant for perrhenate under SLE conditions wherein chloroform serves as the organic phase.

To test our hypothesis that receptor $\mathbf{2}$ could also act as an effective supramolecular extractant for selective removal of perrhenate from solid mixtures containing ppb-level $\mathrm{ReO}_{4}{ }^{-}$, further SLE experiments were carried out using inductively coupled plasma mass spectrometry (ICP-MS). Specifically, solutions of 2 in $\mathrm{CHCl}_{3}(3.0 \mathrm{mM})$ were placed over solid equal-mass mixtures of $\mathrm{NaCl}, \mathrm{NaF}, \mathrm{NaNO}_{3}, \mathrm{NaClO}_{4}, \mathrm{NaH}_{2} \mathrm{PO}_{4}$, $\mathrm{Na}_{2} \mathrm{SO}_{4}$ and $\mathrm{Na}_{2} \mathrm{MoO}_{4}$ containing $800 \mathrm{ppb}, 500 \mathrm{ppb}$, and 200 ppb $\mathrm{NaReO}_{4}$, respectively, and subject to equilibration over time range 0 to $72 \mathrm{~h}$. As shown in Figure S29, after contact of 2 in $\mathrm{CHCl}_{3}$ and the solid mixtures over $6 \mathrm{~h}$, the remaining $\mathrm{ReO}_{4}{ }^{-}$ions in the solid residues were measured to decrease from 800,500 , and $200 \mathrm{ppb}$ to 67,57 , and $42 \mathrm{ppb}$, respectively. Expanding the exposure time to $72 \mathrm{~h}$ led to essentially negligiable extraction of more $\mathrm{ReO}_{4}-$ from the solids to organic phase. The imcomplete conversion could be attributed to the ineffective contact of 2 and $\mathrm{ReO}_{4}$ because of solid inclusion.Taken in concert, these findings above led us to conclude that, under SLE conditions, superphane $\mathbf{2}$ was capable of extracting perrhenate ions with high selectivity from extremely low-content (as low as $200 \mathrm{ppb}$ ) perrhenate sources even in the presence of substantial competing ions. To our knowledge, this is the first example for a host-guest system to complex and extract effectively such small quantities of perrhenate under SLE conditions in the presence of large quantities of competing ions. 
(a)
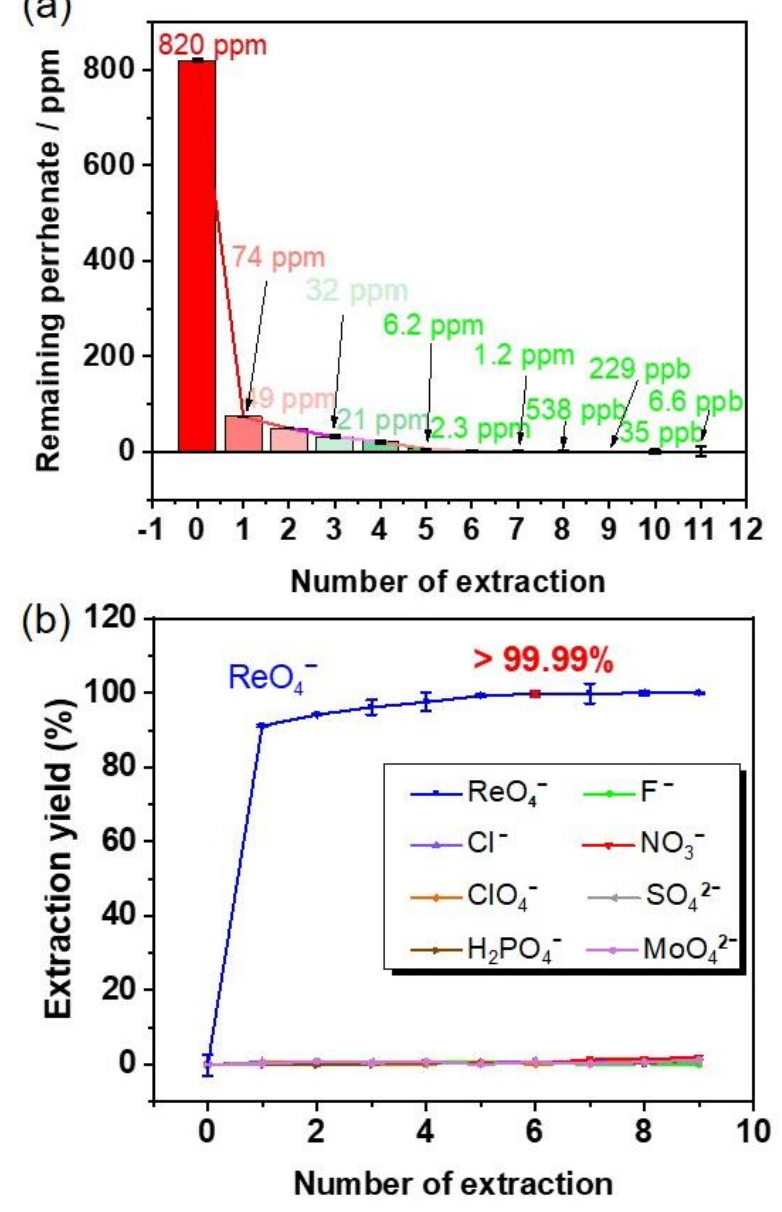

Figure 4. Results of ICP-MS analyses showing (a) the remaining $\mathrm{ReO}_{4}^{-}$(in ppm) in the simulated aqueous waste streams and (b) the extraction yields (\%) after different numbers of extraction. The starting simulated aqueous waste streams consist of equal-molar concentrations (30 mM each) of $\mathrm{NaCl}, \mathrm{NaF}, \mathrm{NaNO}_{3}, \mathrm{NaClO}_{4}, \mathrm{NaH}_{2} \mathrm{PO}_{4}, \mathrm{Na}_{2} \mathrm{SO}_{4}$ and $\mathrm{Na}_{2} \mathrm{MoO}_{4}$ in water containing 820 ppm of $\mathrm{NaReO}_{4}$.

We next sought to explore whether receptor 2 was capable of extracting, inter alia extremely low-content, $\mathrm{ReO}_{4}{ }^{-}$ ions under liquid-liquid extraction (LLE) conditions. Given the exceptional performance of $\mathbf{2}$ for extracting perrhenate anions under SLE conditions, we initialized the LLE studies with a relatively low concentration of $\mathrm{ReO}_{4}^{-}$in aqueous solution using ICP-MS. Specifically, the first stage extraction was performed by well exposing a $3.0 \mathrm{mM}$ solution of 2 (2 $\mathrm{mL}$ ) to a solution of $\mathrm{NaReO}_{4}$ in water at concentration of 820 ppm ( $2 \mathrm{~mL}$ ). After careful separation, the aqueous phase was further subject to multiple rounds of extraction with solutions of $\mathbf{2}$ in chloroform. After each round of extraction, a small amount of the aqueous phase was then separated off and diluted with water for ICP-MS analysis (Figure S30). Much to our delight, the remaining $\mathrm{ReO}_{4}-$ ions in the aqueous phase were observed to sharply decrease from $820 \mathrm{ppm}$ to $1.2 \mathrm{ppm}$ as the number of extraction increased from 1 to 7. Astonishingly, despite the occurrence of $\mathrm{ReO}_{4}^{-}$at ppb level, when the number of extraction continued to increase to 10 , the remaining $\mathrm{ReO}_{4}{ }^{-}$could be further reduced to $<10$ ppb. In terms of the extraction yields, they significantly increased as the number of extraction increased (Figure S31).
Eventually, over six consecutive extractions, > 99.99\% of the perrhenate ions were found able to be removed from the original aqueous solution. Contrastingly, sodium, the counter cation of $\mathrm{ReO}_{4}^{-}$, in the aqueous phase was seen almost constant during the consecutive extractions, indicating that perrhenate was probably plucked out of the aqueous phase by $\mathbf{2}$ in the form of $\mathrm{ReO}_{4}^{-} @ 2 \cdot \mathrm{H}^{+}$, a finding fully in line with what was discussed above. These observations allow us to conclude that superphane 2 was capable of enhancing deep removal of $\mathrm{ReO}_{4^{-}}$, which could lead to practical applications in elimination of $\mathrm{TeO}_{4}{ }^{-}$in the real waste streams.

Encouraged by these results, more efforts were devoted to evaluation of the selectivity of 2 toward $\mathrm{ReO}_{4}$ - in the presence of seven other different potentially competitive anions, viz. $\mathrm{F}^{-}, \mathrm{Cl}^{-}, \mathrm{NO}_{3}^{-}, \mathrm{ClO}_{4}^{-}, \mathrm{H}_{2} \mathrm{PO}_{4}^{-}, \mathrm{SO}_{4}^{2-}$, and $\mathrm{MoO}_{4}^{-}$, simultaneously in water. Concretely, these experiments were carried out by consecutive extraction of a simulated aqueous waste stream, which consists of equal-molar concentrations (30 mM for each) of $\mathrm{NaCl}, \mathrm{NaF}, \mathrm{NaNO}_{3}$, $\mathrm{NaClO}_{4}, \mathrm{NaH}_{2} \mathrm{PO}_{4}, \mathrm{Na}_{2} \mathrm{SO}_{4}$ and $\mathrm{Na}_{2} \mathrm{MoO}_{4}$ in water containing 820 ppm of $\mathrm{NaReO}_{4}$. During the consecutive extractions with solutions of 2 in $\mathrm{CHCl}_{3}$, the remaining $\mathrm{ReO}_{4}^{-}$and other existing potentially competing ions in the aqueous phases were monitored by ICP-MS and ion chromatography, respectively (Figure 4). Expectedly, notwithstanding the presence of a large excess of competitive anions, the remaining $\mathrm{ReO}_{4}{ }^{-}$in aqueous phase was found to decrease sharply (from $820 \mathrm{ppm}$ to $<10 \mathrm{ppb}$ ) while the extraction yields (\%) significantly increased to $>99.99 \%$ with increasing the number of extraction (from 1 to 11). In sharp contrast, almost no appreciable changes were observed for the residual competitive anions, viz. $\mathrm{F}^{-}, \mathrm{Cl}^{-}, \mathrm{NO}_{3}^{-}, \mathrm{ClO}_{4}^{-}, \mathrm{H}_{2} \mathrm{PO}_{4}^{-}, \mathrm{SO}_{4}{ }^{2-}$, and $\mathrm{MoO}_{4}^{-}$, in the aqueous phases, even after ten rounds of extraction (Figure S32). These findings revealed an unprecedented LLE efficiency and selectivity of superphane 2 toward targeted $\mathrm{ReO}_{4}^{-}$over other competitive anions in question.

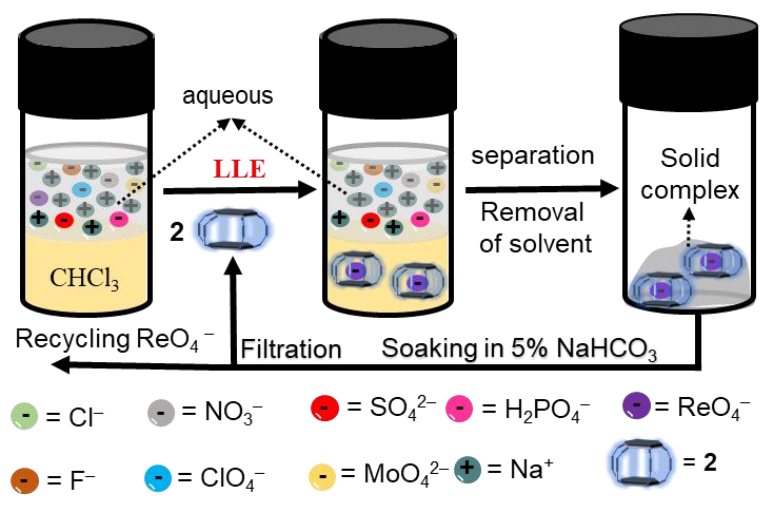

Figure 5. Cartoon illustration of the selective liquid-liquid extraction of $\mathrm{ReO}_{4}$ - from its aqueous mixtures containing a large excess of competing ions and the recycling of superphane extractant and targeted perrhenate.

Finally, in our endeavor to meet the requirements for practical applications, we developed a strategy to recycle and reuse the supramolecular extractant 2 . As illustrated in Figure 5, after each extraction, the chloroform layer was separated off and the organic solvent evaporated. The 
resulting solid $\mathrm{ReO}_{4}^{-} @ 2 \cdot \mathrm{H}^{+}$complex was then soaked and refluxed in a $5 \%$ aqueous solution of $\mathrm{NaHCO}_{3}$ for $12 \mathrm{~h}$. During this process, the perrhenate ions (as acidic form) were "back-extracted" into the aqueous phase and neutralized by $\mathrm{NaHCO}_{3}$. The solid residues were filtered off and subject to ${ }^{1} \mathrm{H}$ NMR spectroscopic analysis. The resulting ${ }^{1} \mathrm{H}$ NMR spectrum proved fully in accord with that of the fresh 2 (Figure S33). This allows us to conclude that superphane 2 was capable of being recycled and reused during the consecutive extraction of perrhenate by a relatively simple and practical operation.

\section{Conclusion}

In summary, a new superphane 2 bearing six amide $\mathrm{NH}$ and six secondary $\mathrm{NH}$ units was synthesized via a reductive amination strategy. This 6-fold symmetric system 2 featuring both liquid and solid emissive fluorescence was found capable of encapsulating perrhenate (as its acidic form) in a 1:1 ratio with an association constant of $K_{a}=$ $(5.62 \pm 0.15) \times 10^{3} \mathrm{M}^{-1}$ in a mixture of $\mathrm{CDCl}_{3}$ and $\mathrm{CD}_{3} \mathrm{OD}(1: 1$, $\mathrm{v} / \mathrm{v}$ ). In a series binding studies, compound 2 displayed high selectivity toward $\mathrm{ReO}_{4}^{-}$over other potential competing anions, viz. $\mathrm{H}_{2} \mathrm{PO}_{4}^{-}, \mathrm{SO}_{4}{ }^{2-}, \mathrm{Cl}^{-}, \mathrm{NO}_{3}{ }^{-}$, and $\mathrm{ClO}_{4}{ }^{-}$. Interestingly, superphane 2 could separate $\mathrm{ReO}_{4}$ - from a complex solid mixture of $\mathrm{NaCl}, \mathrm{NaF}, \mathrm{NaNO}_{3}, \mathrm{NaClO}_{4}, \mathrm{NaH}_{2} \mathrm{PO}_{4}, \mathrm{Na}_{2} \mathrm{SO}_{4}$ and $\mathrm{Na}_{2} \mathrm{MoO}_{4}$ containing extremely low content (as low as 200 ppb) of $\mathrm{NaReO}_{4}$ with circa $100 \%$ selectivity. When used as a supramolecular extractant for LLE, $\mathbf{2}$ was also capable of deeply removing $\mathrm{ReO}_{4}{ }^{-}$from simulated aqueous waste streams containing only $820 \mathrm{ppm}$ of $\mathrm{NaReO}_{4}$ in the presence of a large excess of seven competing ions. Notably, this extractant still works well to extract $\mathrm{ReO}_{4}{ }^{-}$even at ppb level and $>99.99 \%$ of the $\mathrm{ReO}_{4}^{-}$in the complex simulated aqueous waste streams could be removed by consecutive extraction with exceptionally high selectivity. Finally, superphane $\mathbf{2}$ was examplified to be easily recycled and reused for effective removal of targeted $\mathrm{ReO}_{4}{ }^{-}$ions. To the best of our knowledge, this superphane-based extractant represents the first host-guest system for deep removal of $\mathrm{ReO}_{4}^{-}$under both SLE and LLE with unprecedented efficacy and selectivity. Overall, these studies are expected to advance our understanding of the design criteria for producing ion receptors targeted for the recognition and extraction of species of particular interest with exceptional efficiency and selectivity.

\section{Experimental Section}

Synthesis of 6: To a solution of hexakis(aminomethyl)benzene 5 (444 mg, $1.76 \mathrm{mmol}$ ) in $100 \mathrm{~mL}$ of DMSO key intermediate 4 ( $1.8 \mathrm{~g}, 1.47 \mathrm{mmol}$ ) was added. After the mixture was stirred at $60^{\circ} \mathrm{C}$ for $4 \mathrm{~h}$, cooling and filtering, the filter cakes were washed with $\mathrm{MeOH}$. Meanwhile, the filtrate was diluted with $700 \mathrm{~mL}$ of $\mathrm{H}_{2} \mathrm{O}$ and extracted with chloroform ( $2 \times 250 \mathrm{~mL}$ ). The combined organic phase was washed successively with brine and $\mathrm{H}_{2} \mathrm{O}$, followed by drying over anhydrous $\mathrm{Na}_{2} \mathrm{SO}_{4}$. After filtration and concentration under reduced pressure, the combined solids were collected to give 6 as off-white solid (1.30 g, 65\%). ${ }^{1} \mathrm{H}$ NMR (400 MHz, DMSO-d6) $\delta 8.06(\mathrm{~s}, 6 \mathrm{H}), 7.45(\mathrm{~d}, J=4.7 \mathrm{~Hz}, 6 \mathrm{H})$, $7.03(\mathrm{t}, J=7.8 \mathrm{~Hz}, 6 \mathrm{H}), 6.87-6.72(\mathrm{~m}, 18 \mathrm{H}), 5.09(\mathrm{~s}, 12 \mathrm{H})$, $4.51(\mathrm{~d}, J=4.8 \mathrm{~Hz}, 12 \mathrm{H}), 4.12(\mathrm{~s}, 12 \mathrm{H}) .{ }^{13} \mathrm{C}$ NMR $(100 \mathrm{MHz}$,
DMSO-d6) $\delta 166.8,161.6,156.8,138.0,137.5,137.2,129.3$, $121.8,114.9,112.9,66.3,58.0,37.7$. HRMS (ESI) $\mathrm{m} / \mathrm{z}$ : [M + $\mathrm{H}]^{+}$calcd for $\mathrm{C}_{78} \mathrm{H}_{73} \mathrm{~N}_{12} \mathrm{O}_{12}$ 1369.5465, found 1369.5452 .

Synthesis of 2: To a solution of 6 (1.30 g, $0.95 \mathrm{mmol})$ in $100 \mathrm{~mL}$ of $\mathrm{CH}_{2} \mathrm{Cl}_{2} / \mathrm{MeOH}(1: 1, \mathrm{v} / \mathrm{v}) \mathrm{NaBH}_{4}(2.20 \mathrm{~g}, 57 \mathrm{mmol})$ was added in batches. The resulting mixture was stirred at room temperature overnight. Then the precipitates were filtered off and the filtrate was concentrated under reduced pressure. The solid residues were successively washed with $\mathrm{H}_{2} \mathrm{O}$, ethanol and ethyl ether to yield 2 as white solid (1.15 g, 88\%). ${ }^{1} \mathrm{H}$ NMR $\left(400 \mathrm{MHz}, \mathrm{CDCl}_{3}\right) \delta 7.69(\mathrm{~s}, 6 \mathrm{H}), 6.95(\mathrm{t}, J=$ $8.0 \mathrm{~Hz}, 6 \mathrm{H}), 6.76(\mathrm{~s}, 6 \mathrm{H}), 6.60(\mathrm{~d}, J=8.0 \mathrm{~Hz}, 6 \mathrm{H}), 6.45(\mathrm{dd}, J=$ 8.0, $2.6 \mathrm{~Hz}, 6 \mathrm{H}), 4.86(\mathrm{~d}, J=5.5 \mathrm{~Hz}, 12 \mathrm{H}), 4.16(\mathrm{~s}, 12 \mathrm{H}), 3.93$ (s, 12H), $3.58(\mathrm{~s}, 12 \mathrm{H}) \cdot{ }^{13} \mathrm{C}$ NMR $\left(100 \mathrm{MHz}, \mathrm{CDCl}_{3}\right) \delta 169.0$, 157.2, 143.3, 138.3, 138.1, 128.8, 121.2, 114.8, 112.2, 67.6, 53.5, 49.6, 38.3. HRMS (ESI) $\mathrm{m} / \mathrm{z}:[\mathrm{M}+\mathrm{H}]^{+}$calcd for $\mathrm{C}_{78} \mathrm{H}_{85} \mathrm{~N}_{12} \mathrm{O}_{12}$ 1381.6404, found 1381.6400.

\section{ASSOCIATED CONTENT}

\section{Supporting Information}

This material is available free of charge via the Internet at http://pubs.acs.org."

Experimental procedures, NMR spectroscopic studies, HRMS results, fluorescent spectroscopic details, SLE and LLE studies, and $\mathrm{X}$-ray structural data for 2-DMSO, 2- $\mathrm{H}_{2} \mathrm{O}-\mathrm{MeOH}, 2-\mathrm{HReO}$, and $2-\mathrm{NH}_{4} \mathrm{ReO}_{4}$ complex (PDF)

$\mathrm{X}$-ray crystallographic data for 2-DMSO (CIF)

$\mathrm{X}$-ray crystallographic data for $2-\mathrm{H}_{2} \mathrm{O}-\mathrm{MeOH}$ (CIF)

$\mathrm{X}$-ray crystallographic data for $2-\mathrm{HReO}_{4}$ (CIF)

$\mathrm{X}$-ray crystallographic data for $2-\mathrm{NH}_{4} \mathrm{ReO}_{4}$ complexes (CIF)

\section{AUTHOR INFORMATION}

\section{Corresponding Author}

* Qing He: heqing85@hnu.edu.cn

\section{Declaration of Interests}

The authors declare no conflict of interest.

\section{ACKNOWLEDGMENT}

This research was funded by the National Natural Science Foundation of China (22071050 and 21901069 to Q. H.), the Science and Technology Plan Project of Hunan Province, China (Grant No. 2019RS1018 to Q. H.), and Fundamental Research Funds for the Central Universities (Startup Funds to Q. H.). We thank Dr Zhenyi Zhang from Bruker (Beijing) Scientific Technology Co., Ltd for helpful discussions on X-ray crystallography.

\section{REFERENCES}

1. Rouschias, G., Recent advances in the chemistry of rhenium. Chem. Rev. 1974, 74, 531-566.

2. Abisheva, Z. S.; Zagorodnyaya, A. N.; Bekturganov, N. S., Review of technologies for rhenium recovery from mineral raw materials in Kazakhstan. Hydrometallurgy 2011, 109, 1-8.

3. Shen, L. T.; Tesfaye, F.; Li, X. B.; Lindberg, D.; Taskinen, P., Review of rhenium extraction and recycling technologies from primary and secondary resources. Miner. Eng. 2021, 161.

4. Shammugam, S.; Gervais, E.; Schlegl, T.; Rathgeber, A., Raw metal needs and supply risks for the development of wind energy in Germany until 2050. J. Clean. Prod. 2019, 221, 738-752.

5. Moreau, V.; Dos Reis, P. C.; Vuille, F., Enough Metals? Resource Constraints to Supply a Fully Renewable Energy System. Resources 2019, 8. 
6. Watari, T.; Nansai, K.; Nakajima, K., Review of critical metal dynamics to 2050 for 48 elements. Resour. Conserv. Recy. 2020, 155.

7. John, D. A.; Seal Ii, R. R.; Polyak, D. E. Rhenium; 1802P; Reston, VA, 2017; p 62.

8. Free, M., Minor Elements Recovery and Impurity Control in Industrial Metal Processing. Jom-Us 2011, 63, 92-92.

9. Georg Nadler, H., Rhenium and Rhenium Compounds. In Ullmann's Encyclopedia of Industrial Chemistry, Wiley-VCH Verlag GmbH \& Co., KGaA,: Weinheim, 2012.

10. Habashi, F., Extractive metallurgy of rare earths. Can. Metall. Quart. 2013, 52, 224-233.

11. Burgeson, I. E.; Deschane, J. R.; Blanchard, D. L., Removal of technetium from Hanford tank waste supernates. Sep. Sci. Technol. 2005, 40, 201-223.

12. Hassan, N. M.; Adu-Wusu, K.; Nash, C. A.; Marra, J. C., Multiple ion exchange column tests for technetium removal from Hanford site Tank 241-AW-101 with Superlig (R) 639 resin. Solvent. Extr. Ion. Exc. 2004, 22, 663-680.

13. Salehi, H.; Tavakoli, H.; Aboutalebi, M. R.; Samim, H. R., Recovery of molybdenum and rhenium in scrub liquors of fumes and dusts from roasting molybdenite concentrates. Hydrometallurgy 2019, $185,142-148$.

14. Anderson, C. D.; Taylor, P. R.; Anderson, C. G., Extractive metallurgy of rhenium: a review. Miner. Metall. Proc. 2013, 30, 59-73.

15. Banerjee, D.; Kim, D.; Schweiger, M. J.; Kruger, A. A.; Thallapally, P. K., Removal of TcO4-ions from solution: materials and future outlook. Chem. Soc. Rev. 2016, 45, 2724-2739.

16. Hu, Q.-H.; Jiang, W.; Liang, R.-P.; Lin, S.; Qiu, J.-D., Synthesis of imidazolium-based cationic organic polymer for highly efficient and selective removal of $\mathrm{ReO}_{4}{ }^{-} / \mathrm{TcO}_{4}{ }^{-}$. Chem. Eng. J. 2021, 419.

17. Li, A. M.; Zhai, H. J.; Li, J. L.; He, Q., Practical Applications of Supramolecular Extraction with Macrocycles. Chem. Lett. 2020, 49, 1125-1135.

18. Persch, E.; Dumele, O.; Diederich, F., Molecular Recognition in Chemical and Biological Systems. Angew. Chem. Int. Ed. 2015, 54, 3290-3327.

19. Katayev, E. A.; Kolesnikov, G. V.; Sessler, J. L., Molecular recognition of pertechnetate and perrhenate. Chem. Soc. Rev. 2009, 38, 1572-1586.

20. Alberto, R.; Bergamaschi, G.; Braband, H.; Fox, T.; Amendola, V., 99Tc04(-): selective recognition and trapping in aqueous solution. Angew. Chem. Int. Ed. 2012, 51, 9772-6.
21. Zhang, D.; Ronson, T. K.; Mosquera, J.; Martinez, A.; Nitschke, J. R., Selective Anion Extraction and Recovery Using a Fe(II)4 L4 Cage. Angew. Chem. Int. Ed. 2018, 57, 3717-3721.

22. Thevenet, A.; Marie, C.; Tamain, C.; Amendola, V.; Miljkovic, A.; Guillaumont, D.; Boubals, N.; Guilbaud, P., Perrhenate and pertechnetate complexation by an azacryptand in nitric acid medium. Dalton Trans. 2020, 49, 1446-1455.

23. Sekine, Y.; Brown, M.; Boekelheide, V., [2.2.2.2.2.2] $(1,2,3,4,5,6)$ Cyclophane: superphane. J. Am. Chem. Soc. 1979, 101, 3126-3127.

24. Boekelheide, V., [2n]Cyclophanes: paracyclophane to superphane. Acc. Chem. Res. 1980, 13, 65-70.

25. Gleiter, R.; Kratz, D., "Super" phanes. Acc. Chem. Res. 1993, 26, 311-318.

26. Gleiter, R.; Roers, R., Superphanes. Modern Cyclophane Chemistry 2004, 105-129.

27. He, Q.; Li, A.; Xiong, S.; Zhou, W.; Zhai, H.; Liu, Y., Superphanes: Old Yet New Binding-Agents for Highly Selective Recognition of Fluoride by Size-Sieving Effect. ChemRxiv. Preprint 2020, D0I: 10.26434/chemrxiv.13489608.v1.

28. Li, A. M.; Xiong, S. L.; Zhou, W.; Zhai, H. J.; Liu, Y. C.; He, Q., Superphane: a new lantern-like receptor for encapsulation of a water dimer. Chem. Commun. 2021, 57, 4496-4499.

29. Xie, H.; Finnegan, T. J.; Liyana Gunawardana, V. W.; Pavlović, R. Z.; Moore, C. E.; Badjić, J. D., A Hexapodal Capsule for the Recognition of Anions. J. Am. Chem. Soc. 2021, 143, 3874-3880.

30. Spek, A. L., PLATON SQUEEZE: a tool for the calculation of the disordered solvent contribution to the calculated structure factors. Acta Crystallogr. C 2015, 71, 9-18.

31. Holman, K. T.; Halihan, M. M.; Jurisson, S. S.; Atwood, J. L.; Burkhalter, R. S.; Mitchell, A. R.; Steed, J. W., Inclusion of Neutral and Anionic Guests within the Cavity of $\pi$-Metalated Cyclotriveratrylenes. J. Am. Chem. Soc. 1996, 118, 9567-9576.

32. Amendola, V.; Alberti, G.; Bergamaschi, G.; Biesuz, R.; Boiocchi, M.; Ferrito, S.; Schmidtchen, F. P., Cavity Effect on Perrhenate Recognition by Polyammonium Cages. Eur. J. Inorg. Chem. 2012, 3410-3417.

33. Gawenis, J. A.; Holman, K. T.; Atwood, J. L.; Jurisson, S. S., Extraction of Pertechnetate and Perrhenate from Water with Deep-Cavity [CpFe(arene)]+-Derivatized Cyclotriveratrylenes. Inorg. Chem. 2002, 41, 6028-6031. 
Insert Table of Contents artwork here
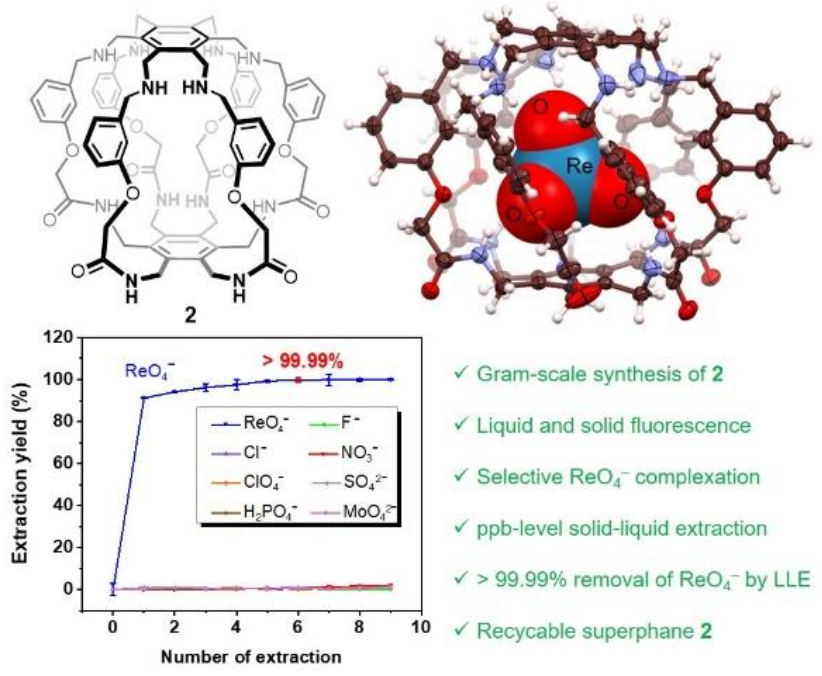